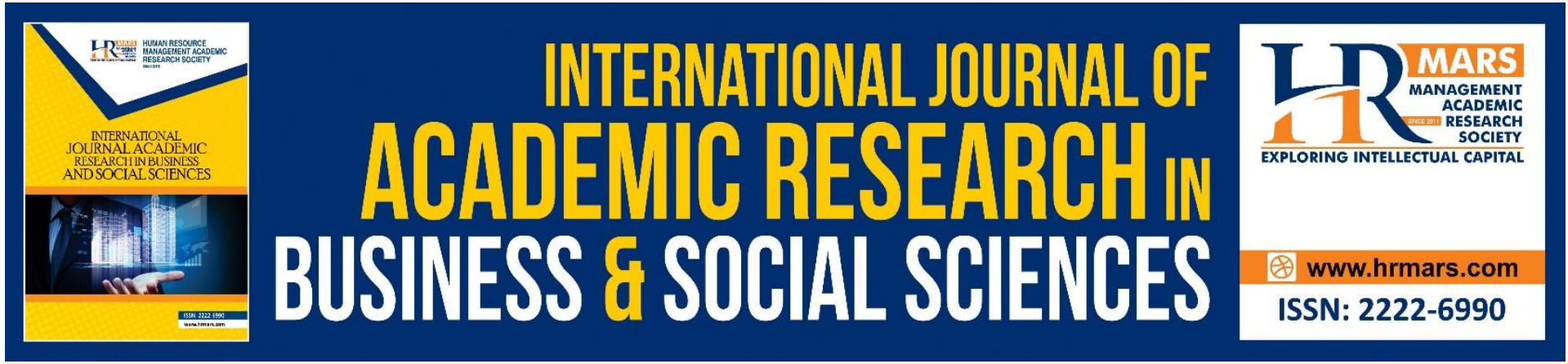

\title{
Language Learning Strategies Used by Form 4 EsI Learners to Develop Speaking Skills
}

Emily John, Devandran Rangasamy, Dinesiriy Indiran, Evelyn Rita Adickalam, Saraswathy Kashinathan, Harwati Hashim

To Link this Article: http://dx.doi.org/10.6007/IJARBSS/v11-i6/10040

DOI:10.6007/IJARBSS/v11-i6/10040

Received: 19 April 2021, Revised: 21 May 2021, Accepted: 05 May 2021

Published Online: 23 June 2021

In-Text Citation: (John et al., 2021)

To Cite this Article: John, E., Rangasamy, D., Indiran, D., Adickalam, E. R., Kashinathan, S., \& Hashim, H. (2021). Language Learning Strategies Used by Form 4 Esl Learners to Develop Speaking Skills. International Journal of Academic Research in Business and Social Sciences, 11(6), 1547-1562.

Copyright: (c) 2021 The Author(s)

Published by Human Resource Management Academic Research Society (www.hrmars.com)

This article is published under the Creative Commons Attribution (CC BY 4.0) license. Anyone may reproduce, distribute, translate and create derivative works of this article (for both commercial and non-commercial purposes), subject to full attribution to the original publication and authors. The full terms of this license may be seen at: http://creativecommons.org/licences/by/4.0/legalcode

Vol. 11, No. 6, 2021, Pg. 1547 - 1562

http://hrmars.com/index.php/pages/detail/IJARBSS

JOURNAL HOMEPAGE

Full Terms \& Conditions of access and use can be found at http://hrmars.com/index.php/pages/detail/publication-ethics 


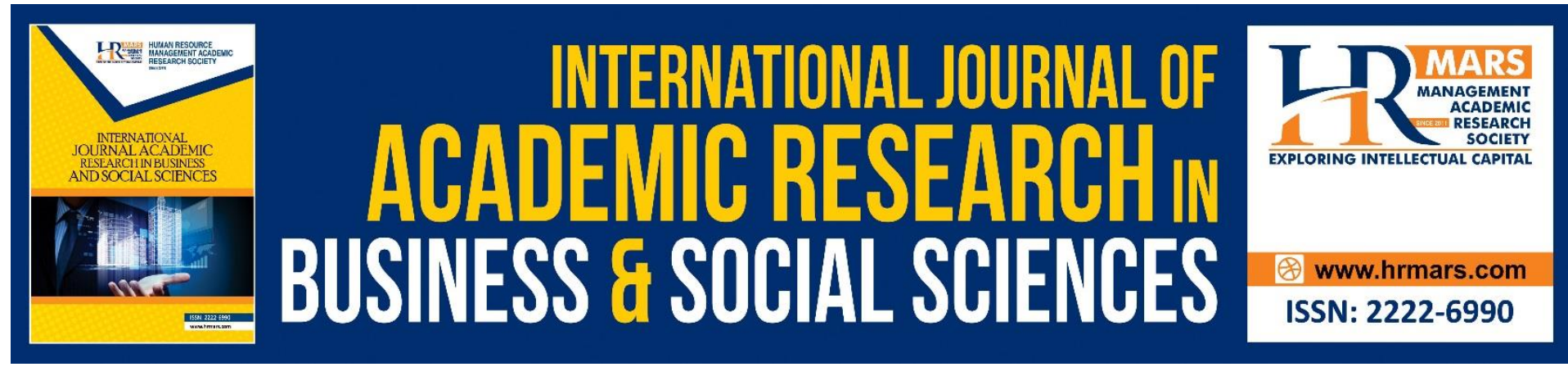

\title{
Language Learning Strategies Used by Form 4 EsI Learners to Develop Speaking Skills
}

\author{
Emily John, Devandran Rangasamy, Dinesiriy Indiran, Evelyn \\ Rita Adickalam, Saraswathy Kashinathan
}

Faculty of Education, Universiti Kebangsaan Malaysia, Selangor 43600, Malaysia

\author{
Harwati Hashim \\ Centre of Innovation in Teaching \& Learning, Faculty of Education, Universiti Kebangsaan \\ Malaysia \\ Email: harwati@ukm.edu.my
}

\begin{abstract}
One of the most crucial elements of learning English is the ability to communicate effectively. It helps the user to convey information orally in a way that listeners can comprehend. It is important to communicate successfully in this global environment and speaking is considered the most critical of the four language skills. The focus of this study is to identify the highly utilized language learning strategies (LLS) among Form 4 ESL learners to improve their speaking skills. 60 students were selected using the purposive sampling method with ages ranging from sixteen to seventeen years old. Oxford (1990) Strategy Inventory for Language Learning (SILL) Version 7.0 was used as the basis of the questionnaire. The modified version consisted of 36 statements on a Likert scale of 1 to 5 . The mean and percentages of each strategy was analysed using SPSS Version 26 . The results revealed that metacognitive strategy is the highly used LLS, while the memory related strategy is the minimally used LLS among upper secondary ESL learners in improving their speaking skills. These findings provide useful information for other researchers who are interested in analysing the language learning strategies used by students to improve their speaking skills.
\end{abstract}

Keywords: Language Learning Strategies (LLS), Speaking Skills, Urban Area, Secondary ESL Learners, Strategy Inventory for Language Learning (SILL)

\section{Introduction}

Speaking is a valuable ability in general since people use it to communicate for a variety of roles and purposes. One of the most top challenges of learning English is to be able to communicate successfully with it (Ahmed, 2018). Nor et al. (2019) mentioned that English should be treated more seriously since it is a two-way path that involves both instructors and students. The researchers also added that educators should make an effort to ensure that their teaching plans are successful and that students' learning is relevant by using a diversified and mixed-method approach that appeals to the majority of students' learning styles and preferences. Since English is considered a universal language and is spoken all over the world, 
it is useful for interacting with people who live in various parts of the world, including different regions, states, nations, and continents (Rao, 2019).

Currently, English is being taught in schools as a second language under the Malaysian education system. As such, the prominence of English has had an impact on the acquisition of speaking skills (Rao, 2019). Speaking English is considered difficult because speakers must be proficient in many aspects: including pronunciation, grammar, vocabulary, fluency, and comprehension. Learners should have sufficient English language skills to interact comfortably and efficiently with others (Leong \& Ahmadi, 2017).

LLS aids English as a Second Language (ESL) students in successfully improving their learning abilities. There are six LLS; which is divided into direct (memory-related, cognitive and compensation); and indirect (metacognitive, affective, and social) strategies. Memoryrelated strategy comprises building mental associations, using images and sound, analysing thoroughly, and taking action. Second, cognitive techniques include things like practising, receiving and sending messages, analysing and reasoning, and putting input and output into a system. Third, compensation strategies involve intelligent guessing and overcoming speaking and writing weaknesses. Fourth will be indirect strategies, such as metacognitive strategies for focusing our learning, organising and coordinating our learning, and assessing our learning. Fifth, affective strategies are attempts to reduce anxiety, motivate ourselves, and keep our emotional temperature in control. Finally, social strategies include things like asking questions, working together with others, and concentrating with others (Oxford, 1990).

Embarrassment, fear, anxiety, lacking in inspiration, bad learning habits, a limited vocabulary as well as a lack of trust, are some of the inhibiting learning factors in speaking (Hanifa, 2018). Lingga et al. (2020) stated that students have difficulties speaking English due to a lack of grammatical comprehension, vocabulary, incorrect pronunciation of words, fear of making errors, lack of self-confidence, and embarrassment. It can be inferred that students find it challenging to communicate in English. Furthermore, they must have an adequate vocabulary and the ability to organise their sentences so that they can be understood in order to communicate fluently and correctly. If all of these aspects are done correctly, the students will be able to talk clearly, and their audience will easily understand what they are saying.

Malaysia is a multilingual country with many languages being spoken. Therefore, English is most probably not the second language for the learners in Malaysia as their own mother tongue and the national Malay language comes first. For some students, English is most often the third or fourth spoken language. Previously, the Primary School Standard (KBSR/KSSR) and Curriculum for Secondary Schools (KBSM/KSSM) were focused on teaching, assessment and assessment reporting and formed based expected outcomes that indicate progress and success. In these curricula, the English language learning skills; reading, writing, listening, and speaking; were not given equal importance to students. The teachers were focused mostly on reading and writing skills in their teaching methods as the Sijil Pelajaran Malaysia (SPM) exam is directed towards those two skills only. The four skills were not given equal importance and attention for the students in the schooling system. According to Sadiku (2015), all four language skills techniques should be used within a teaching hour, but they should be employed at different levels depending on the objectives.

However, in Malaysia, efforts to improve English language success and competency are ongoing, with the most recent master plan being the Common European Framework of Reference (CEFR) for languages which is a recent programme aimed at empowering English speakers (Sabudin, 2019). The CEFR's language model is based on both the action-oriented 
and socio-cognitive approaches, stressing cognitive processes in language learning as well as the role of social meaning in how language is learned and used, (Weir, 2005). In general, the CEFR determines six distinct English language users: A1, A2, B1, B2, C1 \& C2. Language learners are required to perform tasks to gain language input or expertise, according to the blue book's detailed guideline, and techniques are required for language learners to perform tasks, (Council of Europe, 2001). In the CEFR, students are given equal weight in learning all four language skills.

Good language learners are aware of their learning preferences and can experiment with a range of language learning methods to find the one that works best for them. Given the importance of the English language in today's world, research is required to determine the strategies that learners, especially ESL students, use to develop their English language skills.

Thus, the objective of the study is to:

1. investigate the highly used language learning strategies among Form 4 ESL learners in improving their speaking skills.

2. Investigate the minimally used language learning strategies among Form 4 ESL learners in improving their speaking skills.

\section{Literature Review Speaking Skills}

Babies aged between 6 to 9 months start their speaking by babbling in syllables and imitating tones and speech sounds, (Piaget \& Inhelder, 1972). By the age of one or two years, they would have learned approximately 50 words and will be able to join two words together to form a simple sentence. That is how a child learns to talk at a young age.

Children improve their speaking skill according to their surroundings even though it may be challenging. However, these obstacles do not deter them from attempting to communicate. They would make every effort to adapt and adopt to their changing surroundings. Assimilation and accommodation are two mechanisms used by individuals in an effort to acclimatize. All these mechanisms are seen in a person's life as they respond to their surroundings in more challenging ways,

Figure 1 Children speech development over time

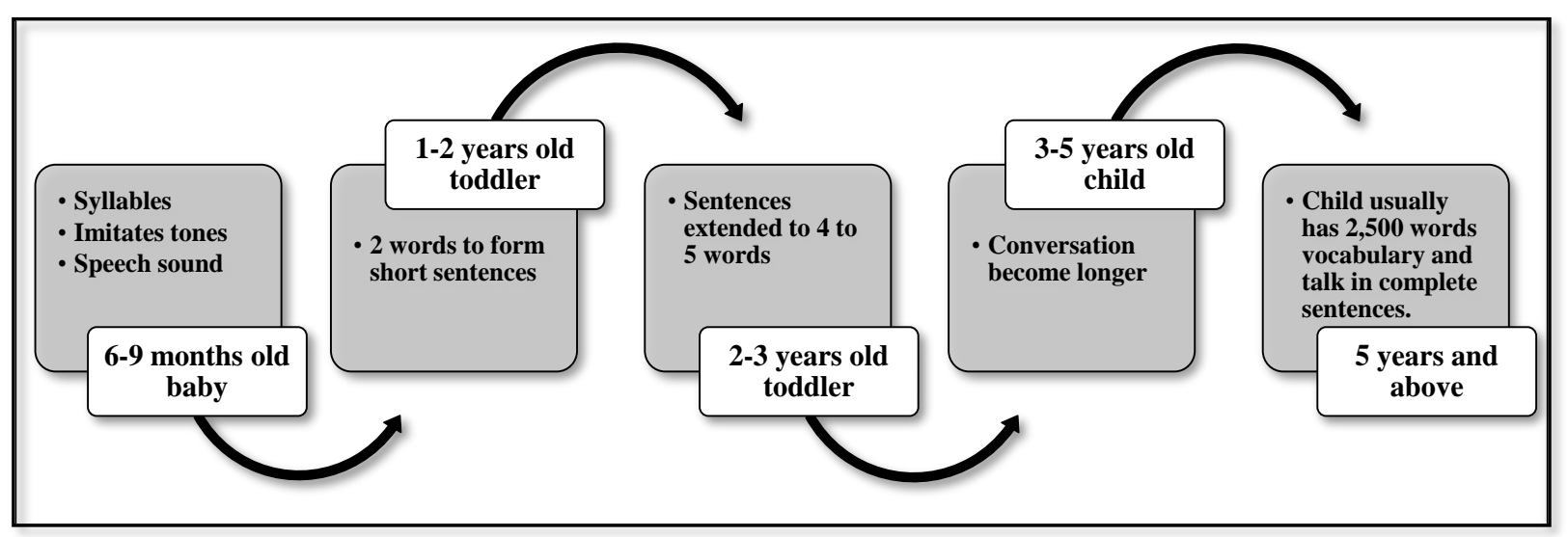

Ur (1999) and Bertram (2002) both perceived speaking as a vital language skill as speaking helps in reading and writing proficiency as well as communicative competence 
among L2 learners. Wenden (1998); Yang (2007) further explained that to enhance students' speaking skills and their complete communicative accomplishment, LLS is vital to create good language learners who have the skills needed for the reception and production of L2 (Yang, 2007; Wenden, 1998). LLS have a significant effect on learners' integrative, instrumental, and overall motivation ( $\mathrm{Wu}, 2008)$. Furthermore, the application of LLS is important and beneficial in promoting awareness and improving speech proficiency (Oxford, 1990).

Speaking is described as an interactive method of creating meaning via the development, retrieval, and processing of knowledge (Burns \& Joyce, 1997). Following a review of recent literature on defining speaking, it was discovered that there are two major approaches to defining speaking: bottom-up and top-down approaches.

Gan (2012) revealed the common issues faced by the students which include insufficient vocabularies, difficult language structure, inappropriate intonation and pronunciation, lack of opportunities in speaking English and inadequate of language curriculum development. Therefore, if teachers are to know how to develop speaking skills, they must first consider what and how they can teach. Teachers in second language classrooms can teach students how to use and practise various techniques that will help them deal with challenging circumstances.

The only way to educate students in this direction is to have a set of lessons in which they become aware of the various options available for them. It could be summarised that teachers should boost their students' speaking skills and communication strategies; what they need to do is structure their lessons around two key questions: what they want to say, which basic speaking skills they want to build in their students, and how they want to do it. Consequently, teachers should introduce LLS to attain a successful communication skill among their students.

\section{Language Learning Strategies}

Students' Language Learning Strategies are the distinct practises or considerations they use to upgrade their language learning methods. Figure 2 shows the classification of language learning strategies since 1975s until today's date from 3 different authors. Rubin (1975) is among one of the earliest researchers who researched a variety of learning strategies. Good L2 learners, according to him, are eager and unerring guessers, have a strong desire to interact, are always unreserved, are inclined to practise opportunities, track their own and others' expressions, and pay attention to sense. Following this, O'Malley, et al. (1985) discovered three categories of language learning strategies: metacognitive, emotional, and social or affective.

Oxford (1990) later classified the strategies into two categories: direct and indirect. Memory, cognitive, and compensation strategies are direct strategies that are specifically involved in understanding the target language. Memory strategies deal with storing and retrieving information in a foreign language. The mental processes involved in manipulating, transforming, and communicating with the target language are referred to as cognitive strategies. Learners use compensation strategies to overcome information gaps that prevent them from learning and producing the target language.

Indirect strategies are those that help the interaction of the language without being specifically linked to the interaction of the language. Metacognitive, affective, and social strategies are also included in this category. Planning, monitoring, and assessing the target language are all facets of metacognitive strategies. Affective strategies are methods that learners use to cope with their feelings and outlooks toward language learning. Finally, social 
strategies are described by their ability to increase target language engagement through interaction with others. To summarise, LLS are unique methods of dealing with knowledge that learners practice to improve comprehension, learning, and recollection of knowledge. Learners use LLS to aid in the comprehension of new knowledge and the resolution of language difficulties.

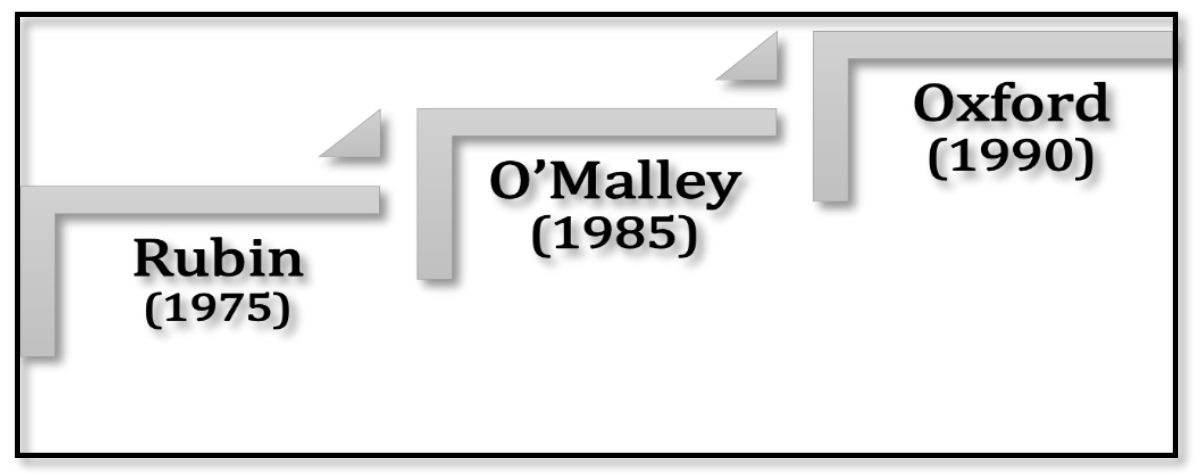

Figure 2 -the classification of language learning strategies

According to Yunus and Singh (2014), in contrast to metacognitive and affective strategies; social strategies is higher and more important. Academic, educational, and personal factors influenced the use of social strategies, while low trust and a difficulty finding good speakers influenced the usage of meta-cognitive and affective strategies. Furthermore, high-performing speaking students were more balanced in their use of various LLS to improve their speaking abilities. For low-performing speaking students, the case was not the same. However, as opposed to low-performing students, high-performing students used more deliberate and appropriate LLS, (Gani et al., 2015). A research was conducted in a secondary school; where the result showed the most used strategies among the female students had a higher propensity in the use of LLS to improve their speaking skills, (Zakaria et al., 2018).

Based on previous studies, it can be determined that different researchers found different results about LLS even though they had used similar language learning analysis. It is because students are born with different genetic; even their deoxyribonucleic acid (DNA) patterns are different. Moreover, they are also different by thoughts, socio backgrounds, prior knowledge, self-esteem and ability. This is one of the reasons why different LLS are practised and it caters different needs of the students. Educators should know what is LLS and how to apply Strategy Inventory for Language Learning (SILL) with the aim to identify students' learning styles.

\section{Strategy Inventory for Language Learning (SILL)}

According to Oxford and Burry-Stock (1995), language learning strategies can be reviewed in one of the most ubiquitous ways which is to use a questionnaire that applies a summative rating scale.

The SILL, widely verified for its reliability and validity, is seen as the main method to collect data regarding LLA. With a choice of five Likert-scale responses, learners are asked to state their responses from one to five for each of the statements or questions asked under each strategy. The format aligns with a sizeable collection of systematically vetted questions and proportional benchmark data which makes it ideal for larger questionnaires with multiple items such as Oxford's (1990) SILL questionnaire, (Newson, 2021). Apart from English Language, there are other languages that had adapted the SILL questionnaire for LLS related research. For instance, an investigation was conducted on students' tendencies in their Arabic 
and English learning strategies usage. The researchers therefore used SILL questionnaire which was adapted from Oxford (1990) version 7.0 for ESL/EFL learners as the instrument for data collection method.

\section{Methodology}

\section{Research Design}

A quantitative descriptive research was conducted using the survey method for this study. The data collected was to investigate what are the highly used and minimally used Language Learning Strategies employed by Form 4 ESL secondary learners in improving their Speaking skills. For the purpose of collecting data for the research, a survey questionnaire comprising of 36 survey questions was used.

\section{Research Instrument}

The instrument utilised for this research was a survey questionnaire modified from the Oxford (1990) Strategy Inventory for Language Learning (SILL) Version 7.0 which looks at the participants' frequency of the strategies used in second language learning. According to Mizumoto (2018), the use of the SILL questionnaire is widespread due to its user-friendliness in LLS research. This questionnaire was modified to a simpler version to cater to the focus of the study on Speaking skills. There are 36 statements from 6 parts in the questionnaire which looked at the Language Learning Strategy in relation to Speaking skills for all six categories; memory, cognitive, compensation, metacognitive, affective and social, comprising both direct and indirect strategies as shown in Table 1 below.

\section{Table 1}

\section{Questionnaire Description}

\begin{tabular}{|c|c|c|}
\hline \multicolumn{2}{|c|}{ STRATEGY } & PART \\
\hline \multirow{3}{*}{ 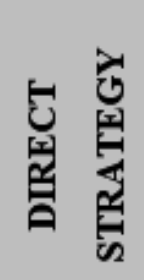 } & MEMORY & PART A \\
\hline & COGNITIVE & PART B \\
\hline & COMPENSATION & PART C \\
\hline \multirow{3}{*}{ 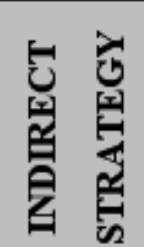 } & METACOGNITIVE & PART D \\
\hline & AFFECTIVE & PART E \\
\hline & SOCIAL & PART F \\
\hline
\end{tabular}

A Likert scale was employed to highlight how the participants responded to the statements by choosing from 1: Strongly Disagree, 2: Disagree, 3: Not Sure, 4: Agreed and 5: Strongly Agree. This scale is shown in the table below. 
Table 2

Likert Scale Description for Each Questionnaire Statement

\begin{tabular}{|c|c|}
\hline SCALE & DESCRIPTION \\
\hline 1 & Totally Disagree \\
\hline 2 & Disagree \\
\hline 3 & Not Sure \\
\hline 4 & Agree \\
\hline 5 & Totally Agree \\
\hline \hline
\end{tabular}

\section{Research Sample}

The purposive sampling method was applied in the selection process of the sample for the study. The respondents were 60 Form 4 students who were selected from one of the researchers' school. There were 28 males (46.7\%) and 32 females (53.3\%) in the sample. 11 of the students were 17 years old as they had gone through the Remove Class and the other 49 students were 16 years old. The students' proficiency level for Speaking based on the Classroom Assessment ranged from weak to advance. However, most of the students are in the average category with very little speaking exposure outside the classroom. All of the students are from the surrounding areas of the school and many are from the lower-socio economic status.

\section{Data Collection Method}

The data was collected using a 5-point Likert questionnaire modified from Strategy Inventory for Language Learning (SILL) Version 7.0, (Oxford \& Burry-Stock, 1995). 36 statements were prepared with 6 statements for each category. All the statements were focused on collecting information about how the respondents acquire the Speaking skills. The questionnaire was administered face-to-face during the English language lessons and collected immediately after the students had responded to the questionnaire.

\section{Data Analysis Method}

The researchers employed a quantitative descriptive research method with statistical analysis to investigate the highly used and minimally used Language Learning Strategies for Speaking skills. The Statistical Package for Social Science (SPSS) was used to analyse the data and to calculate the frequency, percentage, and mean score for each of the strategy.

\section{Findings}

This study investigated 36 direct and indirect strategies in secondary school students' language learning. The findings are presented in 3 tables regarding the aims of the study and the research questions. The questionnaires analysed provides evidence of indirect strategies being used more (above 70\%) than the direct strategies. The study found that metacognitive 
strategies are used the most, and memory-related strategies are used the least among the students.

Table 3

Mean Score and Percentages for Each Strategy

\begin{tabular}{|c|c|c|c|}
\hline \multicolumn{2}{|c|}{ Language Learning Strategies } & Mean Score & Percentage (\%) \\
\hline \multirow{3}{*}{$\begin{array}{c}\text { Direct } \\
\text { Strategies }\end{array}$} & Memory Related & 3.2528 & 65.06 \\
\cline { 2 - 4 } & Cognitive & 3.5806 & 71.61 \\
\cline { 2 - 4 } & Compensation & 3.4917 & 69.83 \\
\hline \multirow{3}{*}{$\begin{array}{c}\text { Indirect } \\
\text { Strategies }\end{array}$} & Metacognitive & 3.7195 & 74.39 \\
\cline { 2 - 4 } & Affective & 3.5667 & 70.44 \\
\cline { 2 - 4 } & Social & 3.6111 & 70.60 \\
\hline
\end{tabular}

Focusing on the first research question of the study, Table 3 describes that the upper secondary students are inclined towards using the language learning strategies in a certain order. They preferred to use metacognitive strategies $(M=3.7195)$, followed by cognitive strategies $(M=3.5806)$, affective strategies $(M=3.5667)$, social strategies $(M=3.6111)$, compensation strategies ( $M=3.4917)$, and finally memory strategies $(M=3.2528)$.

The highly utilized strategy to improve their speaking skills is metacognitive strategy. Based on Table 1, $74.39 \%$ of upper secondary students used metacognition to learn and improve speaking in the English language. With the help of $21^{\text {st }}$ century learning, hand phones have become a central part of learning. As all the students have access to cognitive tools such as computers, hand phones and the internet, they are expected to be able to think critically, work independently and be self-sufficient. Hence, metacognitive strategies enable the students to be in charge of their own learning process; thus, becoming the most used strategy among them.

The least preferred strategy is the memory related strategy. Table 3 indicates that only $65.06 \%$ of upper secondary students use memory strategies to improve on their speaking skills. One of the most common occurrences among students is having to study for countless of hours and end up forgetting some important information during the examination. The failure to bring over things that are studied from their sensory memory to long term memory causes students to forget things easily. This may have been a reason to why memory related strategies are the least favorable among the young upper secondary students. 


\section{Table 4}

\section{Mean Score for Specific Metacognitive Strategies}

\begin{tabular}{|c|c|c|}
\hline $\begin{array}{l}\text { Language } \\
\text { Learning } \\
\text { Strategy }\end{array}$ & Specific Strategies & Mean Score \\
\hline \multirow{6}{*}{ Metacognitive } & $\begin{array}{l}\text { I try to find as many ways as I can to } \\
\text { use my English. }\end{array}$ & 3.7167 \\
\hline & $\begin{array}{l}\text { I notice my English mistakes and use } \\
\text { that information to help me do better. }\end{array}$ & 3.8167 \\
\hline & $\begin{array}{l}\text { I try to find out how to be a better } \\
\text { learner of English. }\end{array}$ & 3.7667 \\
\hline & $\begin{array}{l}\text { I pay attention when someone is } \\
\text { speaking English. }\end{array}$ & 4.0333 \\
\hline & $\begin{array}{l}\text { I have clear goals for improving my } \\
\text { English skills. }\end{array}$ & 3.4333 \\
\hline & $\begin{array}{l}\text { I think about my progress in learning } \\
\text { English. }\end{array}$ & 3.5500 \\
\hline
\end{tabular}

Table 4 specifies the statements and mean scores for the most used metacognitive strategy among upper secondary pupils. The metacognitive section includes 6 statements namely: 1) I try to find as many ways as I can to use my English $(M=3.7167), 2)$ I notice my English mistakes and use that information to help me do better $(M=3.8167), 3)$ I try to find out how to be a better learner of English ( $M=3.7667), 4)$ I pay attention when someone is speaking English $(M=4.0333), 5)$ I have clear goals for improving my English skills $(M=3.4333)$ and lastly 6$)$ I think about my progress in learning English $(\mathrm{M}=3.5500)$. The most used metacognitive strategy is "paying attention when someone is speaking in English".

\section{Table 5}

\section{Mean Score for Specific Memory-Related Strategies}

\begin{tabular}{|c|c|c|}
\hline $\begin{array}{l}\text { Language } \\
\text { Learning } \\
\text { Strategy } \\
\end{array}$ & Specific Strategies & Mean Score \\
\hline \multirow{6}{*}{ Memory Related } & $\begin{array}{l}\text { I use new English words in a sentence } \\
\text { so I can remember them. }\end{array}$ & 3.3167 \\
\hline & $\begin{array}{l}\text { I connect the sound to the image of the } \\
\text { word in English to help me remember. }\end{array}$ & 3.3500 \\
\hline & $\begin{array}{l}\text { I remember a new English word by } \\
\text { making a mental picture of a situation } \\
\text { in which the word might be used. }\end{array}$ & 3.1833 \\
\hline & I physically act out new English words. & 3.0500 \\
\hline & I review English lessons often. & 3.2333 \\
\hline & $\begin{array}{l}\text { I remember new English words or } \\
\text { phrases by remembering their location } \\
\text { on the page, on the board, or on a street } \\
\text { sign. }\end{array}$ & 3.3833 \\
\hline
\end{tabular}


Table 5 indicates the statements and mean scores for the least used memory related strategy. The memory related section includes 6 statements as well namely: 1) I use new English words in a sentence so I can remember them $(M=3.3167), 2)$ I connect the sound to the image of the word in English to help me remember $(M=3.3500), 3)$ I remember a new English word by making a mental picture of a situation in which the word might be used (M = 3.1833), 4) I physically act out new English words ( $M=3.0500), 5$ ) I review English lessons often ( $M=3.2333$ ), and finally 6 ) I remember new English words or phrases by remembering their location on the page, on the board, or on a street sign $(M=3.3833)$. The least used memory related strategy is physically acting out the new English words.

\section{Discussion}

The findings indicate that the metacognitive strategies are the most used strategy among others by the upper secondary students in improving their speaking skills. The most used metacognitive strategy is the specified statement "I pay attention when someone is speaking English.". This supports previous studies that indicated speaking has the highest correlation with the metacognitive language learning strategy, (Forbes \& Fisher, 2018; Ghapanchi \& Taheryan, 2012).

Nelson and Narens (1994), who developed the monitoring and control theory asserts that metacognition can essentially be divided into 2 sections: 1) monitoring and 2) control. Both monitoring and control are two meta processes that are interacting with one another. Both these processes ultimately control one's thought processes and their subsequent actions. Monitoring implies the act of observing, reflecting and being able to experience a learning moment. The learning moment, as Pintrich (2002) asserts, can be said as knowledge about cognition, as well as the awareness of and knowledge of one's own cognition. As Livingston (2003) puts it, metacognition is generally thinking about thinking. As students are conscious of the development of metacognitive knowledge, they are being able to be self-aware, selfreflect, self-critic and also self-regulate their own teaching and learning process.

When the students had their judgement of learning, as evident by them choosing their level of speaking proficiency in the survey, it shows mastery and understanding of their Englishspeaking skills. The judgment which would have been done in some point in their lives has brought them to be aware of their state of cognition vs their goals.

One such knowledge of awareness is being aware of different cognitive tasks. As opposed to "what" and "how" of learning to speak in English, students use of "when" and "why" (HongNam \& Leavell, 2006). Paying attention when one is speaking in English is a classic of noticing "when". This describes the fact that it is easier to notice and pick the language when it is in use as compared to reading or speaking anonymously.

With a margin of difference of 0.1 and less, the results of the study also show closer mean scores between 3 metacognitive tasks: "finding ways to use English", "noticing their mistakes in speaking" and "learning how to be better when speaking in English". This shows that the upper secondary students are able to figure out the second part of metacognition; control. As students know their strengths and weakness through their judgements of learning, they would know where they stand in their journey to reach their goals, in this case to speak proficiently in English. The self-knowledge (Flavell, 1979) helps them in weighing the pros and cons of a learning situation., which in turn affects their decision making. Based on the results of the study, students seem eager to find ways to use English in daily conversations. Noticing their own mistakes and learning how to be a better when speaking in English allows proves the fact that they understand "why" a need is there to improve their speaking skills. 
The findings also reveal that the memory strategies are the most underused strategies when learning how to speak in English. This aligns with previous studies conducted by several researchers (Hong-Nam \& Leavell, 2005; Griffiths \& Parr, 2001; Bremner, 1999). As students believe and use metacognitive strategy the most, the said strategy is also the reason on why memory related strategies are used minimally as compared to the rest of the strategies. They evaluate success of any type of learning strategy, (Oxford, 2003) to enhance their speaking proficiency. In this case, memory strategies are preferred less by them.

In this study, the age of the students plays a major role in understanding why the memory related strategy was the least used in learning how to speak in English. As the students in the study are between the ages of 16 and 17, it can be said that they are in the formal operational stage (Piaget, 2003) intellectually. Brown (2000) stated that it is here that they become capable of abstraction, which goes beyond concrete experience and unmediated perception. Therefore, indirect learning strategy such as metacognition precedes direct memory strategy in learning how to speak English proficiently.

The secondary factor that might influence students' decision to prefer other strategies than memory would be the notion of systematic forgetting. Theory of learning implies that as students make progress in learning towards a more communicative level, subsumption takes place, (Ausubel, 1962). The subsumption theory rejects the conditioning, imitating and rote learning methods in language learning. To be progressive in comprehension and production of a language, students tend to internalize the rules and notions of the language.

Camos and Barrouillet (2011) explain that time does not have a direct influence of forgetfulness or systematic forgetting, but the interference of subsequent events do. The increasing number of items in the composite memory will make the brain to focus on newer memory as opposed to the older ones. Without any repetitions, the memory will not travel to the long term section. Vocabulary and tenses not used repetitively, shyness and anxiety which causes communication to cease and not practiced daily will cause the memory to prune over time, (Brown, 2000).

Among older children, Camos and Barroulliet (2011) said that they have the capability to briefly divert attention during processing periods to refresh traces of memory. They can reactivate their memories depending on their cognitive load of processing. Indirectly, this means that memory capacity is needed to remember words to be able to conjure sentences and speak proficiently. This reaffirms with Kron-Sperl et al. (2008) who state that the memory capability of students impacts the efficacy of a learning strategy.

As such, the results of the study indicate students do use multiple memory related strategies, even though it is lesser than the other strategies by a mere of $9.33 \%$ of metacognitive strategies. As students, learning essentially involves memorizing a multitude of information day in and day out. Memory strategies such as the ones used in this research 1) using English words in a sentence; 2 ) connecting sounds to imagery; 3 ) creating a situation that may use an English word; 4) reviewing lessons; 5) acting out new English words; and lastly 6) remembering words via mental locations are helpful in remembering words and information which will be productive in speaking proficiently.

Amongst the 6 memory strategies, "acting out new English words" were the least used overall by students. This may be the results of affective and cultural hindrance amongst them. The concept of inhibition as postulated by Brown (2000) asserts that as we become adults, the defensive nature mounts up to protect our fragile ego, to ward off ideas, experiences and feelings that intimidate us. From this point of view, shyness and anxiety 
both may be factors that inhibit students to physically act up words for fear of being laughed at or judged by others.

\section{Conclusion \& Implication}

This research looked at the highly used and minimally used language learning strategies among Form 4 ESL learners in improving their speaking skills. According to the data collected, it can be inferred that students used both direct and indirect LLS; the percentage ranged between $65 \%$ to $74 \%$. Most students used cognitive strategy in direct strategies, while in indirect strategies they used mostly metacognitive strategy. The results indicated that metacognitive strategy was the most used, while memory related strategy was the most minimally used by the Form 4 ESL learners. This research has shown that students are mindful of their learning process. The students knew and aware about what they seek to do to improve their speaking skills using the metacognitive strategy. They overcome their difficulties in understanding the materials and delivering the presentation to be more organized, comprehend, and confidence in speaking English. The use of metacognitive strategy revealed that the students used it in a varied form, both intentionally and unintentionally.

Memory related strategy helps students to recall and retrieve new knowledge. It helps students in connecting one idea to another, but they do not need deep understanding. Students may use a variety of memory-related methods to learn and retrieve information in a logical order. For example, they employ new English words in a sentence, connect the sound to the image of the word and act out the new English words physically. Memory related strategy may not be as famous as other strategies among the secondary school students because they prefer technology infused learning materials.

The findings of this study reinforce the notion of using language learning strategies to educators who are interested in further research, with many learning methods available today, which they can improvise and investigate further based on their students' learning styles. It is also suggested that researchers use the SILL questionnaire to adapt and find learners' LLS in other language skills such as listening, reading, writing and grammar. Likewise, teachers of other language subjects such as Malay, Chinese and Tamil could use this research as a reference to Investigate their students' language learning strategies. It is also recommended that researchers explore language learning techniques by adapting materials to modern teaching and learning via online platforms during this pandemic time. Apart from that, this study contributes to the relevant literature in many ways. First, this research advances the understanding of L2 learners' language learning strategies in improving their speaking skills. By exploring the strategies used by L2 learners, this study extends the language learning strategies research to urban secondary school level as well as in strategies used by learners in improving their own speaking skills in the absence of teachers or more knowledgeable others (MKO). Second, this study adds further evidence to the effect of metacognitive knowledge in self-management of learning and processing information for $\mathrm{L} 2$ productive speaking skills. To sum up, this study provides new insight to help teachers understand their L2 learners and assist them in utilising language learning strategies to enhance communicative language skills. 


\section{References}

Ahmed, D. I. A. H. (2018). Problems in English communicating skills for learners of English. International Journal of Contemporary Research and Review, 9(07), 20484-20491. https://doi.org/10.15520/ijcrr/2018/9/07/548

Ausubel, D. P. (1962). A Subsumption Theory of Meaningful Verbal Learning and Retention. The Journal of General Psychology, 66(2), 213-224. https://doi.org/10.1080/00221309.1962.9711837

Bertram, G. (2002). The Importance of Oral Language in the School Curriculum. New Zealand: Ministry of Education, New Zealand Government.

Bremner, S. (1999). Language learning strategies and language proficiency: investigating the relationship in Hong Kong. Canadian Modern Language Review, 55(4), 490-514. https://doi.org/10.3138/cmlr.55.4.490

Brown, H. D. (2000). Principles of language learning and teaching. (Vol. 4). New York: Longman.

Burns, A., \& Joyce, H. (1997). Focus on Speaking. Sydney: National Centre for English Language Teaching and Research, Macquarie University.

Camos, V., \& Barrouillet, P. (2011). Developmental change in working memory strategies: From passive maintenance to active refreshing. Developmental Psychology, 47(3), 898-904. https://doi.org/10.1037/a0023193

Council of Europe. Council for Cultural Co-operation. Education Committee. Modern Languages Division. (2001). Common European Framework of Reference for Languages: learning, teaching, assessment. Cambridge University Press.

Flavell, J. H. (1979). Metacognition and cognitive monitoring: A new area of cognitivedevelopmental inquiry. American Psychologist, 34(10), 906-911. https://doi.org/10.1037/0003-066x.34.10.906

Forbes, K., \& Fisher, L. (2015). The impact of expanding advanced level secondary school students' awareness and use of metacognitive learning strategies on confidence and proficiency in foreign language speaking skills. The Language Learning Journal, 46(2), 173-185. https://doi.org/10.1080/09571736.2015.1010448

Gan, Z. (2012). Understanding L2 Speaking Problems: Implications for ESL Curriculum Development in a Teacher Training Institution in Hong Kong. Australian Journal of Teacher Education, 37(1). https://doi.org/10.14221/ajte.2012v37n1.4

Gani, S.A., Fajrina, D., \& Hanifa, R. (2015). Students' learning strategies for developing speaking ability. Studies in English Language and Education, 2(1), 16. https://doi.org/10.24815/siele.v2i1.2232

Ghapanchi, Z., \& Taheryan, A. (2012). Roles of Linguistic Knowledge, Metacognitive Knowledge and Metacognitive Strategy Use in Speaking and Listening Proficiency of Iranian EFL Learners. World Journal of Education, 2(4). https://doi.org/10.5430/wje.v2n4p64

Griffiths, C., \& Parr, J. M. (2001). Language-learning strategies: Theory and perception. ELT Journal, 55(3), 247-254.

Hanifa, R. (2018). Factors generating anxiety when learning EFL speaking skills. Studies in English Language and Education, 5(2), 230-239. https://doi.org/10.24815/siele.v5i2.10932

Hong-Nam, K., \& Leavell, A. G. (2006). Language learning strategy use of ESL students in an intensive English learning context. System, 34(3), 399-415.

https://doi.org/10.1016/j.system.2006.02.002 
Kron-Sperl, V., Schneider, W., \& Hasselhorn, M. (2008). The development and effectiveness of memory strategies in kindergarten and elementary school: Findings from the Würzburg and Göttingen longitudinal memory studies. Cognitive Development, 23(1), 79-104. https://doi.org/10.1016/j.cogdev.2007.08.011

Leong, L. M., \& Ahmadi, S. M. (2017). An analysis of factors influencing learners' English speaking skill. International Journal of Research in English Education, 2(1), 34-41. https://doi.org/10.18869/acadpub.ijree.2.1.34

Lingga, L. M., Simanjuntak, R. M., \& Sembiring, Y. (2020). Students' strategies in learning speaking skills at SMP NASRANI 3 MEDAN. Journal of Languages and Language Teaching, 8(1), 91. https://doi.org/10.33394/jollt.v8i1.2238

Livingston, J. A. (2003). Metacognition: An Overview. Retrieved from Institute of Education Sciences (ERIC): https://eric.ed.gov/?id=ED474273

Mizumoto, A. (2018). On Questionnaire Use in Language Learning Strategies Research. The Journal of Asia TEFL, 15(1), 184-192. https://doi.org/10.18823/asiatefl.2018.15.1.12.184

Mohd Nor, K., Mohd Razali, M., Talib, N., Ahmad, N., Sakarji, S. R., Wan Mohamed Saferdin, W. A. A., \& Mohd Nor, A. (2019). Students' problems in learning English as a second language among MDAB students at UITM Malacca. International Journal of Humanities, Philosophy and Language, 2(7), 01-12. https://doi.org/10.35631/ijhpl.27001

Nelson, T. O., \& Narens, L. (1994). Why investigate metacognition. Metacognition: Knowing about knowing, 13, 1-25.

Newson, P. (28 January, 2021). 12 Reasons Why The 5-Point Likert Scale is a Universal Sentiment Measurement. Retrieved from WorkTango: https://worktango.com/2021/01/28/12-reasons-why-the-5-point-likert-scale-is-auniversal-sentiment-measurement/

O’Malley, J. M., Chamot, A. U., Stewner-Manzanares, G., Kupper, L., \& Russo, R. P. (1985). Learning strategies used by beginning and intermediate ESL students. Language Learning, 35(1), 21-46. https://doi.org/10.1111/j.1467-1770.1985.tb01013.x

Oxford, R. L. (1990). Language Learning Strategies: What Every Teacher Should Know. New York: Newbury House Publishers.

Oxford, R. L. (2003). Language learning styles and strategies: An overview. Oxford: Gala.

Oxford, R. L., \& Burry-Stock, J. A. (1995). Assessing the use of language learning strategies worldwide with the ESL/EFL version of the Strategy Inventory for Language Learning (SILL). System, 23(1), 1-23. https://doi.org/10.1016/0346-251x(94)00047-a

Piaget, J. (2003). Part I: Cognitive Development in Children-Piaget Development and Learning. Journal of Research in Science Teaching, 40.

Piaget, J., \& Inhelder, B. (1972). The Psychology of the Child. New York: Basic Books.

Pintrich, P. R. (2002). The Role of Metacognitive Knowledge in Learning, Teaching, and Assessing. Theory Into Practice, 41(4), 219-225. https://doi.org/10.1207/s15430421tip4104_3

Rao, P. S. (2019). The importance of speaking skills in English classrooms. Alford Council of International English \& Literature Journal (ACIELJ), 2(2), 6-18.

Rubin, J. (1975). What the "Good Language Learner" Can Teach Us. TESOL Quarterly, 9(1), 41. https://doi.org/10.2307/3586011 
Sabudin, M. S. (11 June, 2019). CEFR: A New Initiative to Empower English. Retrieved from www.pendidik.com.my : https://www.pendidik.com.my/2019/06/11/cefr-a-newinitiative-to-empower-english/

Sadiku, L. M. (2015). The importance of four skills reading, speaking, writing, listening in a lesson hour. European Journal of Language and Literature, 1(1), 29. https://doi.org/10.26417/ejls.v1i1.p29-31

Ur, P. (1999). A Course in English Language Teaching. United Kingdom: Cambridge University Press.

Weir, J. P. (2005). Quantifying test-retest reliability using the intraclass correlation coefficient and the SEM. The Journal of Strength and Conditioning Research, 19(1), 231. https://doi.org/10.1519/15184.1

Wenden, A. L. (1998). Metacognitive knowledge and language learning. Applied Linguistics, 19(4), 515-537.

Wu, Y. L. (2008). Language learning strategies used by students at different proficiency levels. Asian EFL Journal, 10(4), 75-95.

Yang, M. N. (2007). Language learning strategies for junior college students in Taiwan: Investigating ethnicity and proficiency. Asian EFL Journal, 9(2), 35-57.

Yunus, N. M., \& Singh, K. K. A. M. (2014). The use of indirect strategies in speaking: Scanning the MDAB students. Procedia - Social and Behavioral Sciences, 123, 204214. https://doi.org/10.1016/j.sbspro.2014.01.1416

Zakaria, N. Y. K., Zakaria, S. N., \& Azmi, N. E. (2018). Language learning strategies used by secondary schools students in enhancing speaking skills. Creative Education, 09(14), 2357-2366. https://doi.org/10.4236/ce.2018.914176 